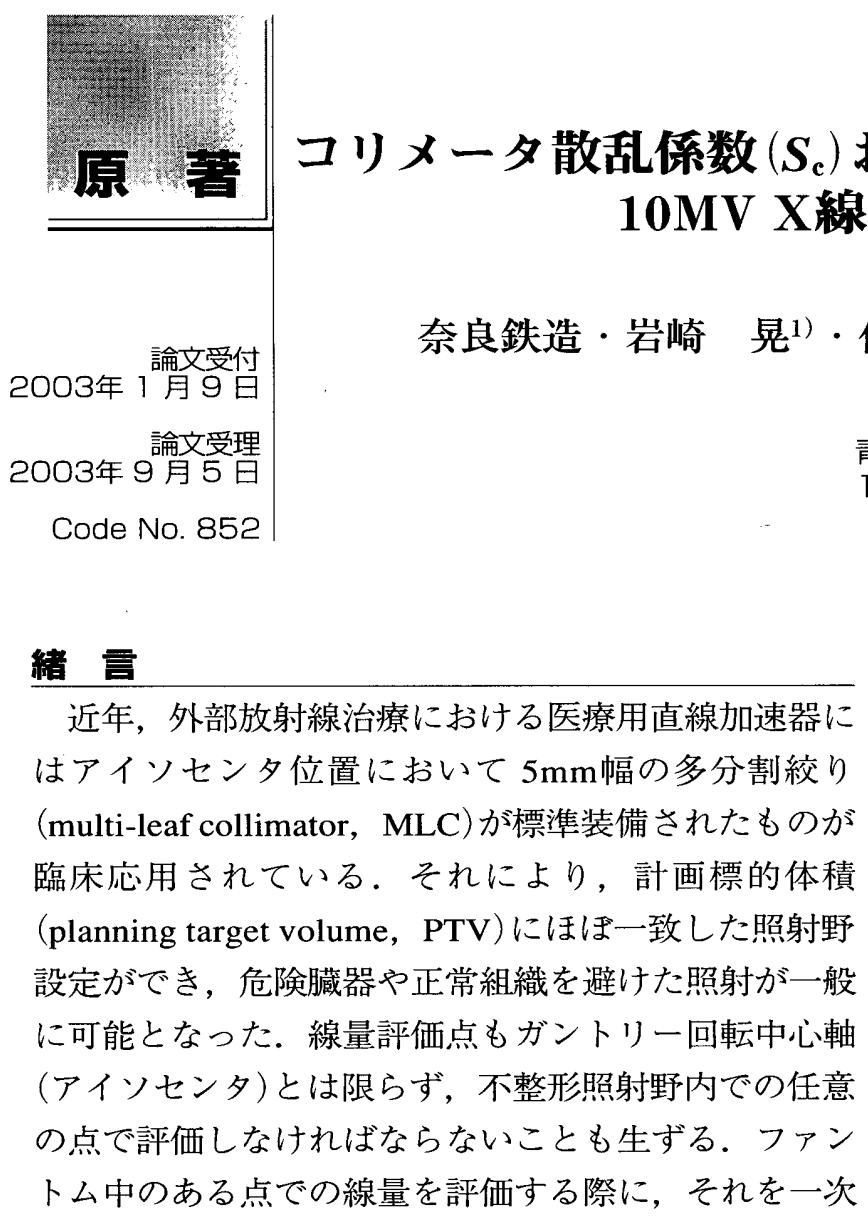

青森県立中央病院放射線科

1 ) 弘前大学医学部保健学科

成分と散乱成分とに分けて行う方法がある。この場 合, Khanらりの提唱したコリメータ散乱係数 $\left(S_{\mathrm{c}}\right)$ およ びファントム散乱係数 $\left(S_{\mathrm{p}}\right)$ を用いることで，照射ヘッ ドからの実効一次線量とファントム内で生ずる散乱線 量とを分離して線量計算を行うことが可能となった.

最近の線量計算 ${ }^{2}$ は，次のとおりである．種々の照 射野について, 基準点出力係数 (output factor, OPF) および深部量百分率(PDD)が知られていれば，基準照 射野 $\left(10 \times 10 \mathrm{~cm}^{2}\right)$ に対する校正点吸収線量を実測する ことにより任意の照射野および深さに対する吸収線量 の計算が一般に可能である。しかし，複雑なMLC不

\title{
Method of Estimating 10 MV X-Ray Irregular Field Dose Using the Collimator Scatter Factor $\left(S_{\mathrm{c}}\right)$ and Phantom Scatter Factor $\left(S_{\mathrm{p}}\right)$
}

\author{
TETSUZO NARA, AKIRA IWASAKI, ') KAZUHIKO SATO, FUMIO KOMAI, HIDETO FUKUSHI, \\ and YOSHIAKI HORANAI
}

Department of Radiology. Aomori Prefectural Center Hospital

1) Hirosaki University School of Health Sciences

Received Jan. 9, 2003; Revision accepted Sept. 5, 2003; Code No. 852

\section{Summary}

It has been found that in general $10 \mathrm{MV} \mathrm{X-ray} \mathrm{dose} \mathrm{calculation} \mathrm{can} \mathrm{be} \mathrm{made} \mathrm{accurately} \mathrm{for} \mathrm{multi-leaf}$ collimator irregular fields by using the total scatter factor $\left(S_{\mathrm{cp}}\right)$, collimator scatter factor $\left(S_{\mathrm{c}}\right)$, and phantom scatter factor $\left(S_{\mathrm{p}}\right)$ proposed by Khan et al. With respect to the collimator scatter factor $\left(S_{\mathrm{c}}\right)$, we used the fieldmapping method of Kim et al. to obtain equivalent square fields of irregular fields (the collimator reverse effect can be accurately dissolved using the field-mapping method). Even for extremely small multi-leaf fields compared with the main collimator opening, X-ray output calculations could be made accurately by introducing the small segment correction (SSC) factor. With respect to the phantom scatter factor $\left(S_{\mathrm{p}}\right)$, highly accurate calculations could be made for irregular field irradiation by applying an $F_{\mathrm{MLC}}$ (MLC radiation leakage) factor to the equivalent square field (in cases in which the ratio of the multi-leaf equivalent square field side to the main collimator equivalent square field side is less than 0.6). However, it has been found that highly accurate dose calculations can, in general, be performed when the main collimator is limited just at the opening determined by the multi-leaf collimator field.

\footnotetext{
W.T. Kords wortimator scatter factor $\left(S_{c}\right)$, Phantom scatter factor $\left(S_{p}\right)$, Small segment correction factor (SSC), Multi-leaf collimator (MLC)
} 
整形照射野を使用する場合，主コリメータかMLC最 大開度まで閉じていない場合およびコリメータ反転効 果3，4）考慮しない空中出力係数を用いる場合には， まだ線量計算精度に問題がある。

今回, われわれはコリメータ散乱係数 $\left(S_{\mathrm{c}}\right)$ およびフ アントム散乱係数 $\left(S_{\mathrm{p}}\right)$ を個別に用いて，上記の問題点 を解決できる不整形照射野線量を評価する一方法を開 発したので以下に報告する。

\section{1. 理骿的肯景}

\section{1-1 不整形照射野に対するSSC係数の算出法}

主コリメー夕照射野に比べて，MLCによって作ら れた不整形照射野が極端に小さい場合には, Jackson ら5)のSSC係数 (small segment correction, SSC) を導入 して する方法がある. 次にSSC係数の算出法を述べる。下 段コリメー夕，MLCおよびアイソセン夕の幾何学的 位置関係から決まる幾何係数 $(G)$ を次式で定義する (Fig. 1).

$$
G=\frac{A \times(C-B)}{B \times(C-A)}
$$

ここで, $A$ は線源から下段コリメー夕の上縁までの距 離，Bは線源からMLCの中間までの距離，Cは線源か らアイソセンタまでの距離である.

次にSSCの補正係数は, 上記の幾何係数 $(G)$ を用 い, 次式で定義される.

$$
S S C=\frac{S_{\mathrm{c}}\left(S_{M L C}^{e q}\right)}{S_{\mathrm{c}}\left(S_{\text {coll }}^{e q} \times G\right)}
$$

ここで， $S_{M L C}^{e q}$ は不整形照射野の等価正方形照射野辺で あり， $S_{\text {coll }}^{\text {あq }}$ は主コリメー夕照射野の等価正方形照射野 辺である. 式(2)より求められるSSCが 1 を超える場 合はSSC=1とする，式(2)はMLCからの散乱X線の影 響を考慮していない(高エネルギーX線の散乱は一般 にビーム進行方向に強く現れる).

不整形照射野のコリメー夕散乱係数 $\left(S_{\mathrm{c}}\right)$ を求める計 算式は次式となる。

$$
S_{\mathrm{c}}(\mathrm{Coll}+\mathrm{MLC})=S_{\mathrm{c}}\left(S_{\text {coll }}^{e q}\right) \times S S C
$$

この具体的な計算例を付録に記す。

この論文では $S_{\text {coll }}^{e q}$ は，Kimの照射野マッピング法で 求めた等価正方形照射野辺を用いた： $S_{M L C}^{e q}$ の值を求め るのに，JacksonらはA/P法を採用しているが，複雑な MLC不整形照射野では必ずしも正確な等価正方形照

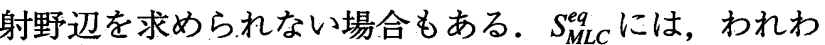
れはファントム散乱係数 $\left(S_{\mathrm{p}}\right)$ を用いたClarkson積分法 を適応させた。この方法を1-2に記述する。

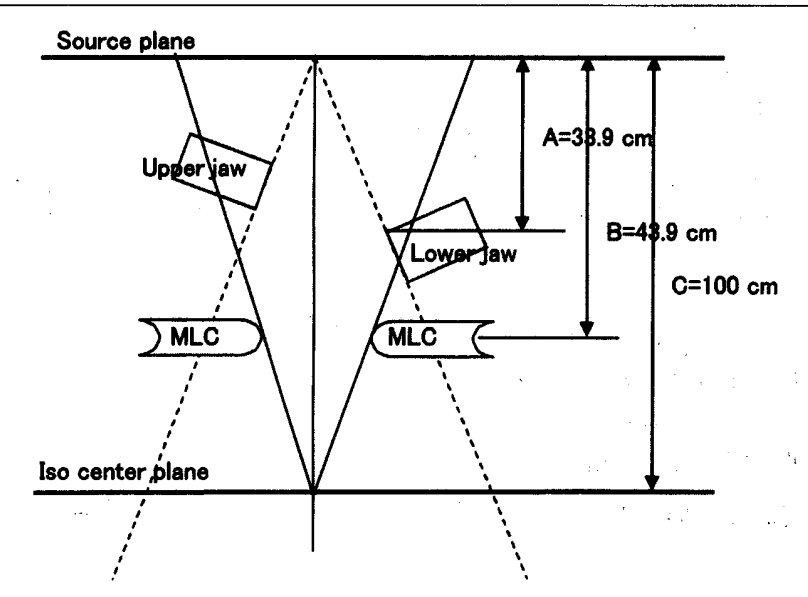

Fig. 1 Schematic diagram used to obtain the geometrical factor $(G)$ for an irregular field. Also shown is the geometric relationship between the lower collimator and the multi-leaf collimator.

\section{1-2 Clarkson積分法による等価照射野の決定}

不整形照射野に対する等価照射野の決定は，両照射 野における散乱線量が一致することが必要である。こ の場合，一次線量は互いに一致するという前提に立っ ている．不整形照射野の散乱線量を直接的に考慮して 等価照射野を決める方法として，下記のものが報告さ れている。

(1) ファントム散乱係数 $\left(S_{\mathrm{p}}\right)$ を用いる方法6)

(2).散乱最大線量比 (scatter-maximum ratio, SMR)を 用いる方法7,8)

（3）散乱係数 (一次線量に対する散乱線量の比) と幾何 学的変数を用いる方法 9

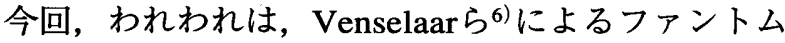
散乱係数 $\left(S_{\mathrm{p}}\right)$ を用いる方法を採用した.この場合，円 形照射野ファントム散乱係数 $\left(S_{\mathrm{p}}\right)$ を用いたClarkson積 分法によって，不整形照射野に対する等価正方形照射 野辺の長さを以下のように求めた(Fig. 2).

$$
S_{\mathrm{p}}=\frac{1}{2 \pi} \sum_{i} S_{\mathrm{p}}\left(r_{i}\right) \Delta \theta_{i}
$$

ここで, $\sum_{i} \Delta \theta_{i}=2 \pi, S_{\mathrm{p}}\left(r_{\mathrm{i}}\right)$ は半径 $r_{\mathrm{i}}$ のファントム散乱 係数 $\left(S_{\mathrm{p}}\right)$ である．等価正方形照射野は上式のファント 厶散乱係数 $\left(S_{\mathrm{p}}\right)$ と同じ值を有する大きさの正方形照射 野とする。

\section{1-3 線量の計算}

STD法における照射で，主コリメータとMLCとで 決まる照射野 $\left(A_{\text {coll }+\mathrm{MLC}}\right)$ のビーム中心軸上の水中で深 さ $(d)$ での線量は次式で求めた.

$$
\begin{array}{r}
D\left(d, A_{\mathrm{coll}+\mathrm{MLC}}\right)=D\left(d_{\mathrm{r}}, 10 \times 10\right) \times S_{\mathrm{c}}(\text { Coll }+\mathrm{MLC}) \\
\times S_{\mathrm{p}}\left(S_{M L C}^{e q} \times F_{\mathrm{MLC}}\right) \times \mathrm{TPR}\left(d, S_{M L C}^{e q} \times F_{\mathrm{MLC}}\right)
\end{array}
$$


ここで, $D\left(d_{\mathrm{r}}, 10 \times 10\right)$ は照射野 $10 \times 10 \mathrm{~cm}^{2}$, 基準深 $d_{\mathrm{r}}$ で の線量である． $S_{\mathrm{c}}($ Coll+MLC)は主コリメータとMLC とで決まるコリメー夕散乱係数 $\left(S_{\mathrm{c}}\right)$ である。 $S_{M L C}^{e q}$ は MLCの等価正方形照射野辺である． $F_{\mathrm{MLC}}$ はMLCから の散乱，透過線量を考慮した補正係数（MLC漏洩補正 係数)であり，設定した主コリメータ正方形照射野辺 に対するMLC正方形照射野辺の比の関数で定義する ( $F_{\mathrm{MLC}}$ は後述するFig. 5から得られる).

$\operatorname{TPR}\left(d, S_{M L C}^{e q} \cdot F_{\mathrm{MLC}}\right)$ は深さ $d$, 等価正方形照射野辺 $\left(S_{M L C}^{e q} \cdot F_{\mathrm{MLC}}\right)$ の組織ファントム線量比 $(\mathrm{TPR})$ である. なお，ファントム散乱係数 $\left(S_{\mathrm{p}}\right)$ おううび組織ファントム 線量比(TPR)の基準深は $d_{\mathrm{r}}$ である.

\section{2. 実験方法}

\section{2-1Ｘ線発生装置}

実験には三菱電機株式会社製医療用直線加速装置 (EXL-15DP) からの10MV X線を用いた。絞り機構は 主コリメータ(上下段コリメータ)と多分割絞り (MLC) からなる。なお，MLCはアイソセン夕位置で $5 \mathrm{~mm}$ 幅 40 対，その両側に $1 \mathrm{~cm}$ 幅10対からなる.

2-2 MLCがかかわるコリメータ散乱係数 $\left(S_{c}\right)$, 全散 乱係数 $\left(S_{\mathrm{cp}}\right)$ およびファントム散乱係数 $\left(S_{\mathrm{p}}\right)$

\section{2-2-1 コリメータ散乱係数 $\left(S_{\mathrm{c}}\right)$ とSSC係数}

主コリメー夕照射野を $6 \times 6,8 \times 8,10 \times 10$ および $16 \times 16 \mathrm{~cm}^{2}$ に設定し，それぞれの内側にMLCで正方形 照射野を作り, SSC係数とコリメー夕散乱係数 $\left(S_{\mathrm{c}}\right)$ の 計算および測定を行った。これらのコリメー夕散乱係 数 $\left(S_{\mathrm{c}}\right)$ の計算には, 式 $(1)$ より求めた幾何係数 $G=0.6554(A=33.9 \mathrm{~cm}, B=43.9 \mathrm{~cm}, C=100 \mathrm{~cm})$ と式 (2) より求めたSSC係数を用いた。ただし，主コリメー夕

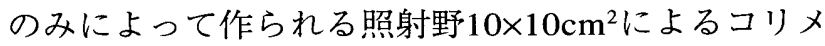
一夕散乱係数 $\left(S_{\mathrm{c}}\right)$ を基準とした。

MLC照射野のコリメー夕散乱係数 $\left(S_{\mathrm{c}}\right)$ の測定は, 次 のように行った.

(I) 検出器には, PTW社製 $0.6 \mathrm{~cm}^{3}$ 指頭形電離箱 $(6.1 \mathrm{~mm} \phi \times 20.7 \mathrm{~mm})$ を用い, X線ビーム軸に対して 検出軸を平行に配置した。電位計にはNE-Technology社製Ionex dosemaster 2590を用いた。

（II）正方形照射野 $1 \times 1 \mathrm{~cm}^{2}$ から $4 \times 4 \mathrm{~cm}^{2}$ までは，アルミ製 ビルドアップキャップ(外径 $2.73 \mathrm{~cm}$, 厚さ $\left.2.88 \mathrm{~g} / \mathrm{cm}^{2}\right)$ を用い, 線源電離箱間距離 $(\mathrm{SCD}) 300 \mathrm{~cm}$ で測定し た.

(III) 正方形照射野 $5 \times 5 \mathrm{~cm}^{2}$ から $16 \times 16 \mathrm{~cm}^{2}$ まではアクリ ル製ミニファントム (断面積 $4 \mathrm{~cm} \Phi$ ，長さ $10 \mathrm{~cm}$, 測定深 $5 \mathrm{~cm}$ ) 用い, 線源電離箱間距離 $(\mathrm{SCD})$ $100 \mathrm{~cm} て ゙$ 測定した.

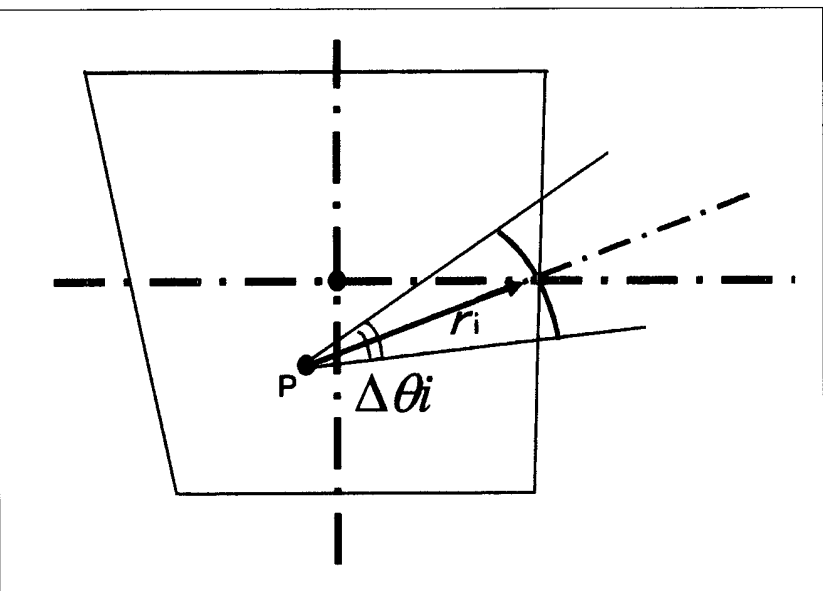

Fig. 2 Diagram showing how to obtain the equivalent square field side using the Clarkson integration method.

\section{2-2-2 全散乱係数 $\left(S_{\mathrm{cp}}\right)$ とファントム散乱係数 $\left(S_{\mathrm{p}}\right)$} 全散乱係数 $\left(S_{\mathrm{cp}}\right)$ は，2-2-1 と同じ組み合わせの主コ リメータ照射野とMLC照射野を用いた。測定は，混 入電子の影響がない水中深 $5 \mathrm{~cm}$ を基準深 $\left(d_{\mathrm{r}}\right)$ とし, 次 のように行った。

(I) 正方形照射野 $1 \times 1 \mathrm{~cm}^{2}$ ではScanditronix社製P-Si type 半導体検出器 $(0.6 \mathrm{~mm} \phi \times 0.5 \mathrm{~mm})$ を用いた $(\mathrm{SCD}$ $100 \mathrm{~cm})$.

(II) 正方形照射野 $2 \times 2 \mathrm{~cm}^{2}$ から $16 \times 16 \mathrm{~cm}^{2}$ まではPTW社 製 $0.015 \mathrm{~cm}^{3}$ 指頭形電離箱 $(2 \mathrm{~mm} \phi \times 5 \mathrm{~mm})$ を用いた $(\mathrm{SCD} 100 \mathrm{~cm})$.

(III) 指頭形電離箱および半導体検出器の電位計には,

NE-Technology社製Ionex dosemaster 2590および Scanditronex社製DPD-3をそれぞれ用いた。

ただし，主コリメータのみによって作られる照射野 $10 \times 10 \mathrm{~cm}^{2}$ よる全散乱係数 $\left(S_{\mathrm{cp}}\right)$ を基準とした. ファン トム散乱係数 $\left(S_{\mathrm{p}}\right)$ は，2-2-1 と同じ組み合わせの主コリ メー夕照射野とMLC照射野に対して, 実測した全散 乱係数 $\left(S_{\mathrm{cp}}\right)$ とコリメー夕散乱係数 $\left(S_{\mathrm{c}}\right)$ を用いて次式に より求めた.

$$
S_{\mathrm{p}}\left(A_{\mathrm{coll}+\mathrm{MLC}}\right)=\frac{S_{\mathrm{cp}}\left(A_{\mathrm{coll}+\mathrm{MLC}}\right)}{S_{\mathrm{c}}\left(A_{\mathrm{coll}+\mathrm{MLC}}\right)}
$$

\section{2-3 MLC洩漏線量の測定}

$10 \times 10 \mathrm{~cm}^{2}$ の主コリメー夕照射野をMLCで全閉した 場合のタフウォータファントム内での線量分布で, MLC洩漏線量を評価した。深さ $5 \mathrm{~cm}$ にイルム (Kodak社製XV2)をX線ビーム軸に対して垂直に置き 照射した。なお, 線源フィルム間距離 $(\mathrm{SFD})$ は $100 \mathrm{~cm}$ とし，濃度計にはCMS社製DynaScanを用いた。

2-4 off-axis distanceの変化に対する線量測定 主コリメー夕照射野を $10 \times 10 \mathrm{~cm}^{2}$ 一定にし，その内 
側にMLC照射野 $4 \times 4 \mathrm{~cm}^{2}$ 作り，MLC照射野の中心位 置をアイソセンタより $0 \sim 3 \mathrm{~cm}$ (off-axis distance, $\mathrm{OAD})$ 変位させた。この場合, 全散乱係数 $\left(S_{\mathrm{cp}}\right)$ に対し ては，それぞれのOADにおいてタフウォータファン トム $5 \mathrm{~cm}$ 深での線量 (主コリメー夕照射野 $10 \times 10 \mathrm{~cm}^{2}$ ) を基準とし，MLC照射野中心での線量を測定した。 コリメータ散乱係数 $\left(S_{\mathrm{c}}\right)$ に対しては，それぞれのOAD において空中線量(主コリメー夕照射野 $10 \times 10 \mathrm{~cm}^{2}$ )を 基準とし，MLC照射野中心での空中線量を測定し た。

\section{2-5 MLC不整形照射野の形状と評価点}

13 種類の主コリメータ・MLC照射野の組み合わせ を作った．それらの形状と評価点をFig. 3に示す.

\section{3. 結 果}

3-1 MLCがかかわるコリメータ散乱係数 $\left(S_{c}\right)$ および SSC係数

MLC照射野使用におけるコリメー夕散乱係数 $\left(S_{\mathrm{c}}\right)$, SSC係数の測定結果および計算結果をTable 1 (a)，（b) およびTable 2(a)，(b)に示す. Table 1 (a)では, 主コ リメー夕照射野が $6 \times 6 \mathrm{~cm}^{2}$ であり，MLC照射野の変化 は $1 \times 1 \mathrm{~cm}^{2}$ から $6 \times 6 \mathrm{~cm}^{2}$ までである. Table 1(b)では, 主コリメー夕照射野が $8 \times 8 \mathrm{~cm}^{2}$ であり，MLC照射野の

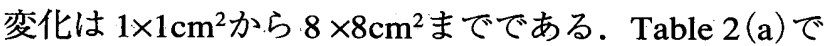
は，主コリメー夕照射野が $10 \times 10 \mathrm{~cm}^{2}$ であり，MLC照 射野の変化は $1 \times 1 \mathrm{~cm}^{2}$ から $10 \times 10 \mathrm{~cm}^{2}$ までである、Table 2(b)では；主コリメー夕照射野が16×16 $\mathrm{cm}^{2}$ であり， MLC照射野の変化は $1 \times 1 \mathrm{~cm}^{2}$ から $16 \times 16 \mathrm{~cm}^{2}$ までであ る.

Table 1(a)，(b) およびTable 2(a)，(b)それぞれに おいてMLC照射野が $1 \times 1 \mathrm{~cm}^{2}$ である場合, 測定值に対 する計算值の相対誤差はSSC係数では平均-2.9\%であ り,コリメータ散乱係数 $\left(S_{\mathrm{c}}\right)$ では平均 $-3.0 \%$ あるる. 他のMLC照射野の場合は，両係数とも約 $\pm 1 \%$ 以下の 相対誤差になっている.

次に：主コリメー夕正方形照射野辺に対するMLC 正方形照射野辺の比とSSC係数 (計算値)の関係を調べ た.その結果をFig. 4に示す.実線で示した近似曲線 が主コリメー夕正方形照射野辺に対するMLC正方形 照射野辺の比(横軸)約 0.64 でSSC係数 1 となる.

\section{3-2. MLC漏洩補正係数 $\left(F_{M L C}\right)$ の算出}

主コリメ一夕照射野 $6 \times 6 \mathrm{~cm}^{2}, 8 \times 8 \mathrm{~cm}^{2}, 10 \times 10 \mathrm{~cm}^{2}$, $16 \times 16 \mathrm{~cm}^{2}$ のそれぞれに対して，内側のMLC照射野を 変化させて, コリメー夕散乱係数 $\left(S_{\mathrm{c}}\right)$, 全散乱係数 $\left(S_{\mathrm{cp}}\right)$ およびファントム散乱係数 $\left(S_{\mathrm{p}}\right)$ の值を求めた。 そ の結果をTable 3(a)，（b）およびTable 4(a)，（b)に示
す。それぞれの表の第 1 項目はMLC照射野である。 第 2 項目は全散乱係数 $\left(S_{\mathrm{cp}}\right)$ である. 第 3 項目はコリ メー夕散乱係数 $\left(S_{\mathrm{c}}\right)$ である. 第 4 項目はファントム散 乱係数 $\left(S_{\mathrm{p}}\right)$ である. 第 5 項目は第 4 項目のファントム 散乱係数 $\left(S_{\mathrm{p}}\right)$ を呈する主コリメータ正方形照射野辺 〔実効正方形照射野辺 (effective square field side)]であ る. 第 6 項目はMLC正方形照射野辺に対する実効正 方形照射野辺の比を表す.

Fig. 5は第 6 項目の結果を用いて作った $F_{\text {MLC }}$ (式 (5) 参照)を表す。ここで, 深さ $2.5 \mathrm{~cm}(\Delta) ; 5 \mathrm{~cm}(\square)$, $10 \mathrm{~cm}(\bigcirc), 15 \mathrm{~cm}(+)$ での主コリメー夕照射野は $6 \times 6$, $8 \times 8 ， 10 \times 10$ おび゙ $16 \times 16 \mathrm{~cm}^{2} て ゙ あ る ．$ 実線は深さ 5 , 10 および $15 \mathrm{~cm}$ での平均值を直線で近似したものであ る (深さ $2.5 \mathrm{~cm}$ での值は, 混入電子の影響のため, 他の 深さでの值に対して全体的に大きく離散しているの で，近似直線を作る場合に除外した）。

\section{3-3. MLC漏洩線量}

タフウォータファントム深 $5 \mathrm{~cm}$ におけるMLC漏洩 線量分布 (フィルム法)をFig. 6に示す. 主コリメ一夕 照射野10×10 $\mathrm{cm}^{2}$ において，MLCを全閉した状態で MLC片軸に対して直角な方向での分布である．ただ し，MLCを全開にした場合の照射野中心における線 量を $100 \%$ とした。コリメータ回転中心軸から正側 3 と 4 番目のMLC間が他のMLC間に比べて漏洩が相対 的に大きくなってている. 平均して約 $4.5 \%$ の漏洩線量 となっている。このようにMLCは主コリメータのよ うな高い遮蔽能力はない.

\section{3-4 off-axis distance(OAD)の変化に対する線量計 算精度}

主コリメー夕正方形照射野の内側に作られたMLC 照射野 $\left(4 \times 4 \mathrm{~cm}^{2}\right)$ の中心がコリメータ回転中心軸より変 位した場合，コリメータ散乱係数 $\left(S_{\mathrm{c}}\right)$ ，ファントム散 乱係数 $\left(S_{\mathrm{p}}\right)$ および組織ファントム線量比 $(\mathrm{TPR})$ に関す る計算結果をFig. 7 とTable 5に示す (この変位方向での 平坦度は良好である)。コリメー夕散乱係数 $\left(S_{\mathrm{c}}\right)$ に関 しては，SSC係数を用いない場合と用いた場合の測定 值に対して，計算值の平均相対誤差はそれぞれ約 2.2 \%および約 $0.22 \%$ あるる.ファントム散乱係数 $\left(S_{\mathrm{p}}\right)$ に 関しては， $F_{\mathrm{MLC}}$ 補正係数を用いない場合と用いた場合 の測定値に対して，計算值の平均相対誤差はそれぞれ

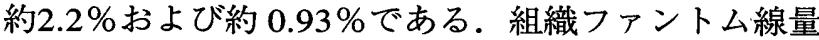
比 (深さ $15 \mathrm{~cm})$ に関しては， $F_{M L C}$ 補正係数を用いない 場合と用いた場合の測定値に対して，計算值の平均相 対誤差はそれぞれ約 $0.3 \%$ および約 $0.6 \%$ である. OADが $2 \mathrm{~cm}$ まではこれらの平均相対誤差は比較的小 さい.このことは，ビーム中心軸上での組織ファント 

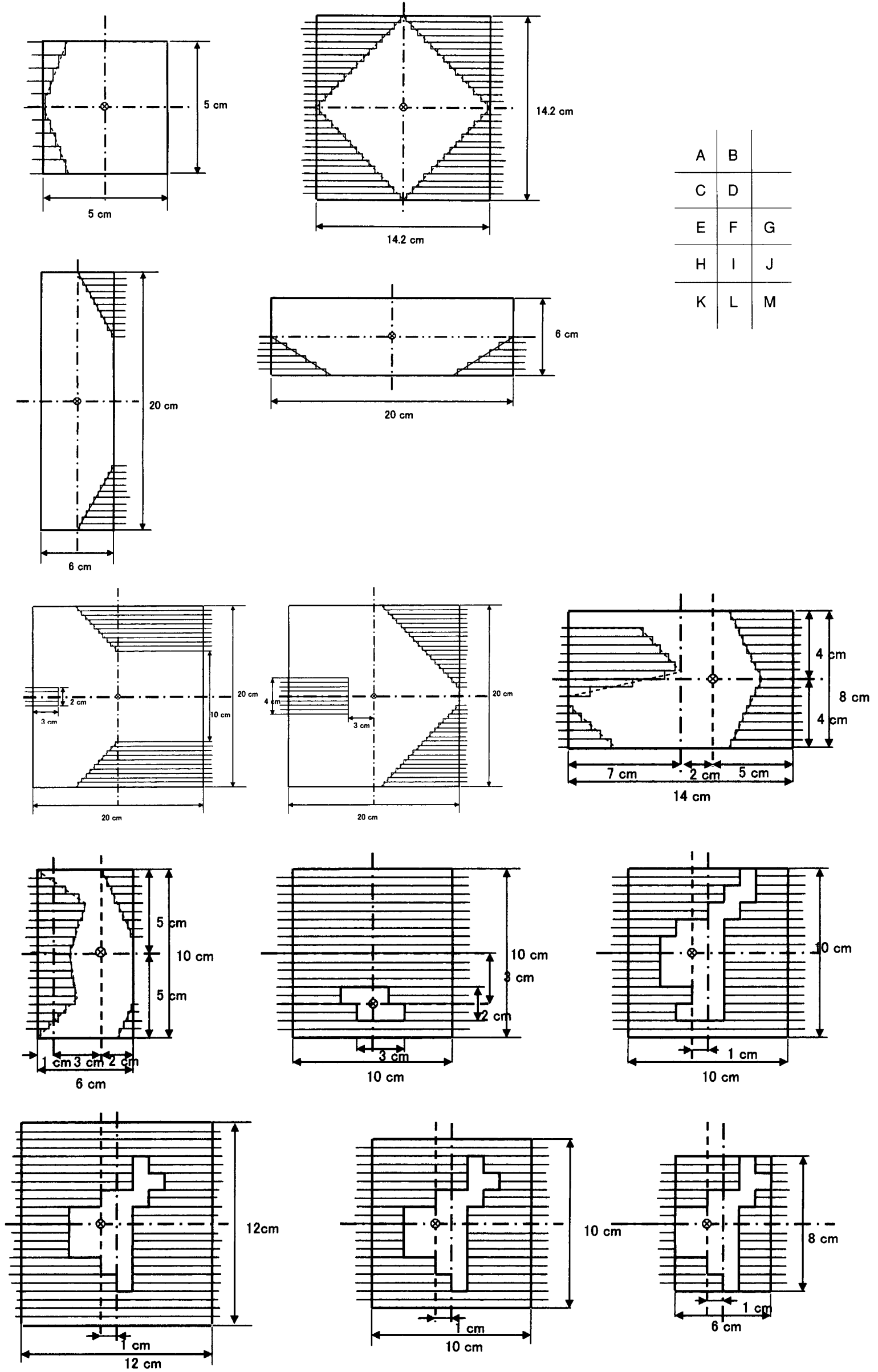

Fig. 3 Shapes of irregular fields A-M and points of dose evaluation. 
Table 1 Small segment corrections (SSC's) for $10 \mathrm{MV} X$-ray irregular fields and the accuracy of the calculated collimator scatter factors $\left(S_{c}\right.$ 's) with main collimator openings of (a) $6 \times 6 \mathrm{~cm}^{2}$ and (b) $8 \times 8 \mathrm{~cm}^{2}$.

(a)

\begin{tabular}{|c|c|c|c|c|c|c|}
\hline \multirow{2}{*}{$\frac{\text { MLC }}{\text { field size }\left(\mathrm{cm}^{2}\right)}$} & \multicolumn{3}{|c|}{ SSC. } & \multicolumn{3}{|c|}{$S_{c}$} \\
\hline & Calculated. & Measured & $\%$ Devi $\left.^{* 1}\right)$ & Calculated & Measured & \%Devi" ${ }^{* 2)}$ \\
\hline $6 \times 6$ & $1(1.0162)$ & 1. & 0.00 & 0.9777 & 0.9788 & -0.11 \\
\hline $5 \times 5$ & $1(1.0080)$ & 1.0003 & -0.03 & 0.9777 & 0.9790 & -0.13 \\
\hline $4 \times 4$ & $1(1.0005)$ & 0.9981 & 0.19 & 0.9777 & 0.9769 & 0.08 \\
\hline $3 \times 3$ & 0.9928 & 0.9915 & 0.13 & 0.9706 & 0.9705 & 0.01 \\
\hline $2 \times 2$ & 0.9843 & 0.9808 & 0.36 & 0.9623 & 0.9600 & 0.24 \\
\hline $1 \times 1$ & 0.9369 & 0.9639 & -2.80 & 0.9159 & 0.9434 & -2.91 \\
\hline (b) & & & & & & - \\
\hline MLC & & SSC & & & $S_{c}$ & \\
\hline field size $\left(\mathrm{cm}^{2}\right)$ & Calculated & Measured & $\%$ Devi $^{* 11}$ & Calculated & Measured & \%Devi"2) \\
\hline $8 \times 8$ & $1(1.0166)$ & 1 & 0.00 & 0.9907 & 0.9892 & 0.15 \\
\hline $7 \times 7$ & $1(1.0103)$ & 1.0002 & -0.02 & 0.9907 & 0.9894 & 0.13 \\
\hline $6 \times 6$ & $1(1.0032)$ & 1.0000 & 0.00 & 0.9907 & 0.9892 & 0.15 \\
\hline $5 \times 5$ & 0.9951 & 0.9973 & -0.22 & 0.9859 & 0.9865 & -0.06 \\
\hline $4 \times 4$ & 0.9877 & 0.9907 & -0.30 & 0.9785 & 0.9800 & -0.15 \\
\hline $3 \times 3$ & 0.9801 & 0.9811 & -0.10 & 0.9710 & 0.9706 & 0.04 \\
\hline $2 \times 2$ & 0.9745 & 0.9696 & 0.51 & 0.9655 & 0.9591 & 0.67 \\
\hline $1 \times 1$ & 0.9249 & 0.9523 & -2.88 & 0.9163 & 0.9420 & -2.73 \\
\hline
\end{tabular}

*1) Relative deviations (\%) of calculated SSC's from the measurements.

*2) Relative deviations (\%) of calculated $S_{\mathrm{c}}$ 's for the MLC fields from the measurements.

Table 2 Small segment corrections (SSC's) for $10 \mathrm{MV} X$-ray irregular fields and the accuracy of the calculated collimator scatter factors $\left(S_{c}\right.$ 's) with main collimator open(a) ings of (a) $10 \times 10 \mathrm{~cm}^{2}$ and (b) $16 \times 16 \mathrm{~cm}^{2}$.

\begin{tabular}{|c|c|c|c|c|c|c|}
\hline \multirow{2}{*}{$\frac{M L C}{\text { field size }\left(\mathrm{cm}^{2}\right)}$} & \multicolumn{3}{|c|}{ SSC } & \multicolumn{3}{|c|}{$S_{c}$} \\
\hline & Calculated & Measured & $\%$ Devi $^{* 11}$ & Calculated & Measured & $\%$ Devi*2) $^{2}$ \\
\hline $10 \times 10$ & $1(1.0189)$ & 1 & 0.00 & 1 & 1 & 0.00 \\
\hline $9 \times 9$ & $1(1.0147)$ & 0.9998 & 0.02 & 1 & 0.9998 & 0.02 \\
\hline $8 \times 8$ & $1(1.0094)$ & 0.9991 & 0.09 & 1 & 0.9991 & 0.09 \\
\hline $7 \times 7$ & $1(1.0031)$ & 0.9976 & 0.24 & 1 & 0.9976 & 0.24 \\
\hline $6 \times 6$ & 0.9961 & 0.9955 & 0.06 & 0.9961 & 0.9955 & 0.06 \\
\hline $5 \times 5$ & 0.9881 & 0.9898 & -0.17 & 0.9881 & 0.9898 & -0.17 \\
\hline $4 \times 4$ & 0.9807 & 0.9813 & -0.06 & 0.9807 & 0.9813 & -0.06 \\
\hline $3 \times 3$ & 0.9732 & 0.9721 & 0.11 & 0.9732 & 0.9721 & 0.11 \\
\hline $2 \times 2$ & 0.9648 & 0.9617 & 0.32 & 0.9648 & 0.9617 & 0.32 \\
\hline $1 \times 1$ & 0.9119 & 0.9396 & -2.95 & 0.9119 & 0.9396 & -2.95 \\
\hline \multicolumn{7}{|l|}{ (b) } \\
\hline MLC & \multicolumn{3}{|c|}{ SSC } & \multicolumn{3}{|c|}{$S_{\mathrm{c}}$} \\
\hline field size $\left(\mathrm{cm}^{2}\right)$ & Calculated & Measured & \%Devi"1) & Calculated & Measured & \%Devi"2) \\
\hline $16 \times 16$ & $1(1.0132)$ & 1 & 0.00 & 1.0148 & 1.0158 & -0.10 \\
\hline $14 \times 14$ & $1(1.0097)$ & 1.0002 & -0.02 & 1.0148 & 1.0161 & -0.13 \\
\hline $12 \times 12$ & $1(1.0049)$ & 0.9998 & 0.02 & 1.0148 & 1.0157 & -0.09 \\
\hline $10 \times 10$ & 0.9984 & 0.9981 & 0.03 & 1.0132 & 1.0139 & -0.07 \\
\hline $8 \times 8$ & 0.9891 & 0.9939 & -0.48 & 1.0038 & 1.0097 & -0.58 \\
\hline $6 \times 6$ & 0.9761 & 0.9849 & -0.89 & 0.9905 & 1.0006 & -1.01 \\
\hline $4 \times 4$ & 0.9610 & 0.9717 & -1.10 & 0.9753 & 0.9871 & -1.20 \\
\hline $2 \times 2$ & 0.9454 & 0.9506 & -0.55 & 0.9594 & 0.9657 & -0.65 \\
\hline $1 \times 1$ & 0.8999 & 0.9310 & -3.34 & 0.9131 & 0.9457 & -3.45 \\
\hline $4 \times 12$ & 0.9761 & 0.9808 & -0.48 & 0.9905 & 0.9974 & -0.69 \\
\hline $2 \times 12$ & 0.9663 & 0.9641 & 0.23 & 0.9806 & 0.9805 & 0.01 \\
\hline
\end{tabular}

*1) Relative deviations $(\%)$ of calculated SSC's from the measurements.

*2) Relative deviations $(\%)$ of calculated $S_{\mathrm{c}}$ 's for the MLC fields from the measurements. 


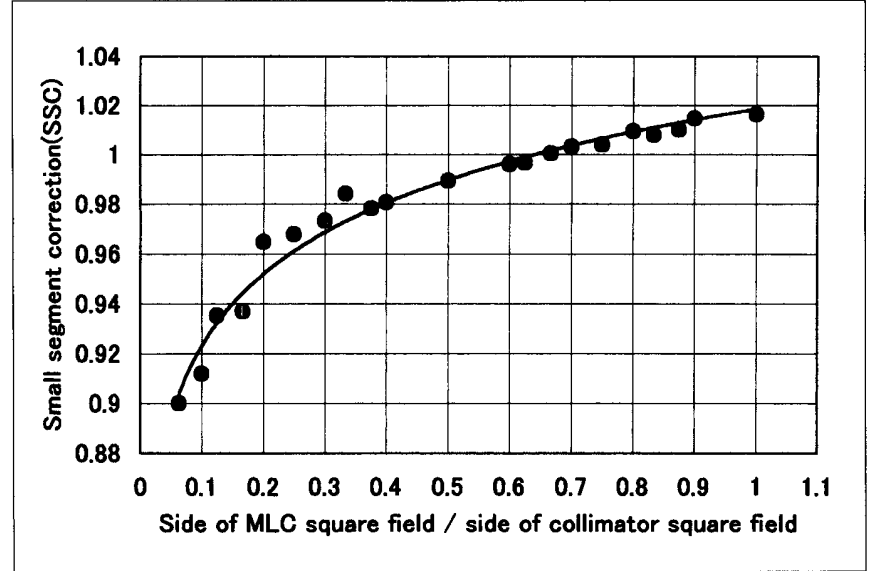

Fig. 4 Diagram showing how the SSC factor varies with the ratio of the MLC square field side to the main collimator square field side.

Table 3 Data on $S_{\mathrm{cp}}$ 's (depth $5 \mathrm{~cm}$ ), $S_{\mathrm{c}}, S_{\mathrm{p}}$ (depth $5 \mathrm{~cm}$ ), and ESFS (effective square field side) as functions of MLC field main collimator openings of (a) $6 \times 6$ $\mathrm{cm}^{2}$ and (b) $8 \times 8 \mathrm{~cm}^{2}$. Values in parentheses indicate the ratio of ESFS/ $M L C$ square field side.

\begin{tabular}{|c|c|c|c|c|c|}
\hline $\begin{array}{c}\text { MLC } \\
\text { field size }\left(\mathrm{cm}^{2}\right)\end{array}$ & $S_{c p}$ & $S_{c}$ & $S_{p}$ & ESFS & ESFS/MLC \\
\hline $6 \times 6$ & 0.9551 & 0.9788 & 0.9758 & 5.66 & $(0.944)$ \\
\hline $5 \times 5$ & 0.9490 & 0.9790 & 0.9694 & 4.95 & $(0.991)$ \\
\hline $4 \times 4$ & 0.9379 & 0.9769 & 0.9601 & 4.27 & $(1.068)$ \\
\hline $3 \times 3$ & 0.9173 & 0.9705 & 0.9452 & 3.31 & $(1.102)$ \\
\hline $2 \times 2$ & 0.8615 & 0.9600 & 0.8974 & 2.51 & $(1.257)$ \\
\hline $1 \times 1$ & 0.7334 & 0.9434 & 0.7774 & 1.22 & (1.223) \\
\hline \multicolumn{6}{|l|}{ (b) } \\
\hline $\begin{array}{c}\text { MLC } \\
\text { field size }\left(\mathrm{cm}^{2}\right)\end{array}$ & $S_{c p}$ & $S_{c}$ & $S_{p}$ & ESFS & ESFS/MLC \\
\hline $8 \times 8$ & 0.9797 & 0.9892 & 0.9904 & 8.02 & $(1.002)$ \\
\hline $7 \times 7$ & 0.9763 & 0.9894 & 0.9868 & 7.33 & $(1.046)$ \\
\hline $6 \times 6$ & 0.9705 & 0.9892 & 0.9811 & 6.40 & $(1.067)$ \\
\hline $5 \times 5$ & 0.9617 & 0.9865 & 0.9749 & 5.55 & $(1.109)$ \\
\hline $4 \times 4$ & 0.9472 & 0.9800 & 0.9665 & 4.71 & $(1.177)$ \\
\hline $3 \times 3$ & 0.9217 & 0.9706 & 0.9496 & 3.39 & $(1.129)$ \\
\hline $2 \times 2$ & 0.8642 & 0.9591 & 0.9011 & 2.59 & $(1.284)$ \\
\hline $1 \times 1$ & 0.7360 & 0.9420 & 0.7813 & 1.25 & $(1.253)$ \\
\hline
\end{tabular}

ム線量比 (TPR)およびファントム散乱係数 $\left(S_{\mathrm{p}}\right)$ デー夕

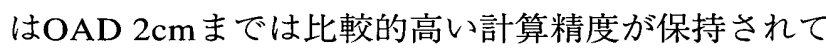
いる.

\section{3-5 不整形照射野の等価正方形照射野辺}

Fig. 3での主コリメータ照射野の等価正方形照射野 辺はKimの照射野マッピング法で求め, MLC照射野の 等価正方形照射野辺は $S_{\mathrm{p}}$-Clarkson積分法を適用して求 めた．それらの結果をTable 6に示す。ここで，不整形 照射野 (A)では, 主コリメー夕照射野が $5 \times 5 \mathrm{~cm}^{2}$ で MLCが少しこの照射野辺縁に入り込んでいる． $S_{\mathrm{p}-}$ Clarkson積分法で求めたMLC照射野の等価正方形照射 野辺は $4.58 \mathrm{~cm}$ である.
不整形照射野 (B)では, 主コリメー夕照射野が $14.2 \times 14.2 \mathrm{~cm}^{2} て ゙$ ，この内側に作ったMLC照射野(菱形) が10×10 $\mathrm{cm}^{2}$ である． $S_{\mathrm{p}}$-Clarkson積分法で求めた等価 正方形照射野辺は $9.84 \mathrm{~cm}(\approx 10 \mathrm{~cm})$ である.

不整形照射野 $(\mathrm{C})$ においては上部コリメー夕開度は $20 \mathrm{~cm}$ であり，不整形照射野(D)においては上部コリメ 一夕開度は $6 \mathrm{~cm}$ である. Kimの照射野マッピング法を 適用したコリメー夕散乱係数 $\left(S_{\mathrm{c}}\right)$ で評価した等価正方 形照射野辺は，不整形照射野 $(\mathrm{C})$ の場合は $11.23 \mathrm{~cm}$ あり，不整形照射野(D)の場合は $7.83 \mathrm{~cm}$ であり，両者 はかなり異なる． $S_{\mathrm{p}}$-Clarkson積分法で求めたMLC照 射野の等価正方形照射野辺は，不整形照射野 (C)の場 合は $8.68 \mathrm{~cm}$ であり，不整形照射野 (D)の場合は $8.74 \mathrm{~cm}$ 
Table 4 Data on $S_{c p}$ 's (depth $5 \mathrm{~cm}$ ), $S_{c}, S_{p}$ (depth $5 \mathrm{~cm}$ ), and ESFS (effective square field side) as function of MLC field main collimator openings of (a) $10 \times 10$ $\mathrm{cm}^{2}$ and (b) $16 \times 16 \mathrm{~cm}^{2}$. Values in parentheses indicate the ratio of ESFS/ (a) MLC square field side.

\begin{tabular}{|c|c|c|c|c|c|}
\hline $\begin{array}{c}\text { MLC } \\
\text { field size }\left(\mathrm{cm}^{2}\right)\end{array}$ & $S_{c p}$ & $s_{\mathrm{c}}$ & $s_{p}$ & ESFS & ESFS/MLC \\
\hline $10 \times 10$ & 0.9993 & 1 & 0.9993 & 9.92 & $(0.992)$ \\
\hline $9 \times 9$ & 0.9966 & 0.9998 & 0.9968 & 9.36 & $(1.039)$ \\
\hline $8 \times 8$ & 0.9918 & 0.9991 & 0.9927 & 8.46 & (1.057) \\
\hline $7 \times 7$ & 0.9867 & 0.9976 & 0.9891 & 7.76 & $(1.108)$ \\
\hline $6 \times 6$ & 0.9794 & 0.9955 & 0.9838 & 6.83 & $(1.139)$ \\
\hline $5 \times 5$ & 0.9688 & 0.9898 & 0.9788 & 6.07 & $(1.215)$ \\
\hline $4 \times 4$ & 0.9517 & 0.9813 & 0.9698 & 5.00 & $(1.250)$ \\
\hline $3 \times 3$ & 0.9247 & 0.9721 & 0.9512 & 3.42 & (1.140) \\
\hline $2 \times 2$ & 0.8678 & 0.9617 & 0.9024 & 2.59 & (1.294) \\
\hline $1 \times 1$ & 0.7392 & 0.9396 & 0.7867 & 1.30 & $(1.296)$ \\
\hline \multicolumn{6}{|l|}{ (b) } \\
\hline $\begin{array}{c}\text { MLC } \\
\text { field size }\left(\mathrm{cm}^{2}\right)\end{array}$ & $S_{c p}$ & $S_{c}$ & $S_{p}$ & ESFS & ESFS/MLC \\
\hline $16 \times 16$ & 1.0333 & 1.0159 & 1.0171 & 15.85 & $(0.991)$ \\
\hline $14 \times 14$ & 1.0316 & 1.0161 & 1.0153 & 14.72 & (1.051) \\
\hline $12 \times 12$ & 1.0264 & 1.0157 & 1.0105 & 12.80 & (1.066) \\
\hline $10 \times 10$ & 1.0185 & 1.0139 & 1.0045 & 10.84 & (1.084) \\
\hline $8 \times 8$ & 1.0077 & 1.0097 & 0.9980 & 9.33 & (1.167) \\
\hline $6 \times 6$ & 0.9899 & 1.0006 & 0.9893 & 7.67 & (1.278) \\
\hline $4 \times 4$ & 0.9591 & 0.9871 & 0.9716 & 5.13 & (1.282) \\
\hline $2 \times 2$ & 0.8733 & 0.9657 & 0.9043 & 2.63 & (1.315) \\
\hline $1 \times 1$ & 0.7441 & 0.9458 & 0.7867 & 1.30 & $(1.296)$ \\
\hline
\end{tabular}

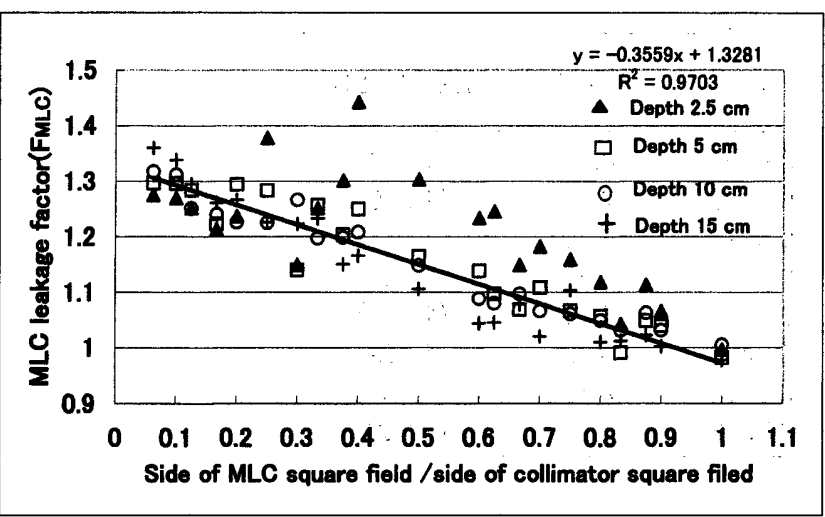

Fig. 5 Correction factors for the $10 \mathrm{MV} \mathrm{X-ray} \mathrm{phantom} \mathrm{scatter}$ factor expressed as a function of the ratio of the main collimator square field side to the MLC square field side. Triangles are for a depth of $2.5 \mathrm{~cm}$, squares for a depth of $5 \mathrm{~cm}$, circles for a depth of $10 \mathrm{~cm}$, and crossed marks for a depth of $15 \mathrm{~cm}$.

であり, 两者はほほ一致する：

不整形照射野 (G)では，主コリメー夕照射野 14×8 $\mathrm{cm}^{2}$ に対して，Kimの照射野マッピング法を適用 したコリメータ散乱係数 $\left(S_{\mathrm{c}}\right)$ で評価した等価正方形照 射野辺は $9.34 \mathrm{~cm}$ であり， $S_{\mathrm{p}}$-Clarkson積分法で求めた MLC照射野の等価照射野辺は6.45 cmである.

非対称不整形照射野 $(\mathbf{H})$ では，コリメータ回転中心 軸が遮られ，線量評価点がX軸上 $3 \mathrm{~cm}$ 変位している。

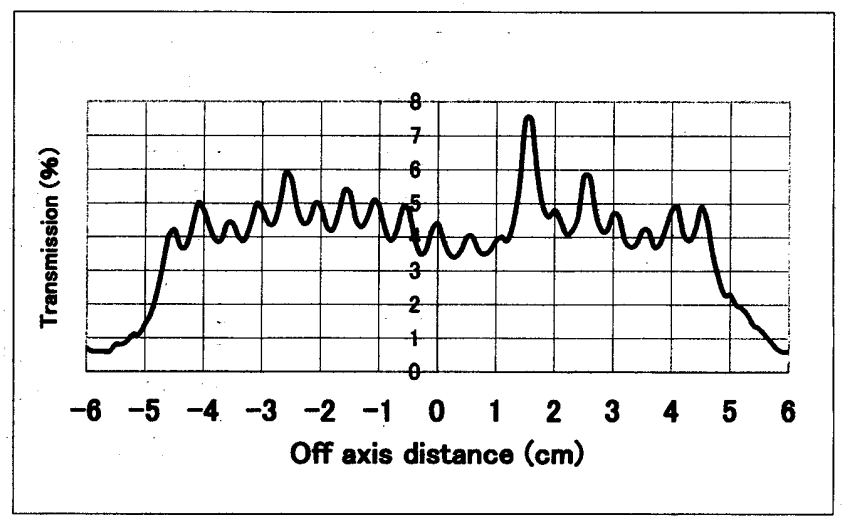

Fig. 6 Dose distribution yielded by $10 \mathrm{MV} X$-rays leaking from the MLC (the main collimator field is $10 \times 10 \mathrm{~cm}^{2}$ and the depth is $5 \mathrm{~cm}$ in water).

主コリメータ照射野が $6 \times 10 \mathrm{~cm}^{2}$ であり，Kimのマッピ ング法を適用したコリメータ散乱係数 $\left(S_{\mathrm{c}}\right)$ による等価 正方形照射野辺は8.18cmである． $S_{\mathrm{p}}$-Clarkson積分法 で求めたMLC照射野の等価正方形照射野辺は $4.53 \mathrm{~cm}$ である。

不整形照射野 (I)では, 主コリメー夕照射野が $10 \times 10 \mathrm{~cm}^{2}$ であり，MLC照射野を $S_{\mathrm{p}}$-Clarkson積分法で 求めた等価正方形照射野辺は $2.07 \mathrm{~cm}$ である.

不整形照射野 (J-M)では, 線量評価点はコリメータ 回転中心軸より，X軸上でそれぞれ-1 cm変位してい 


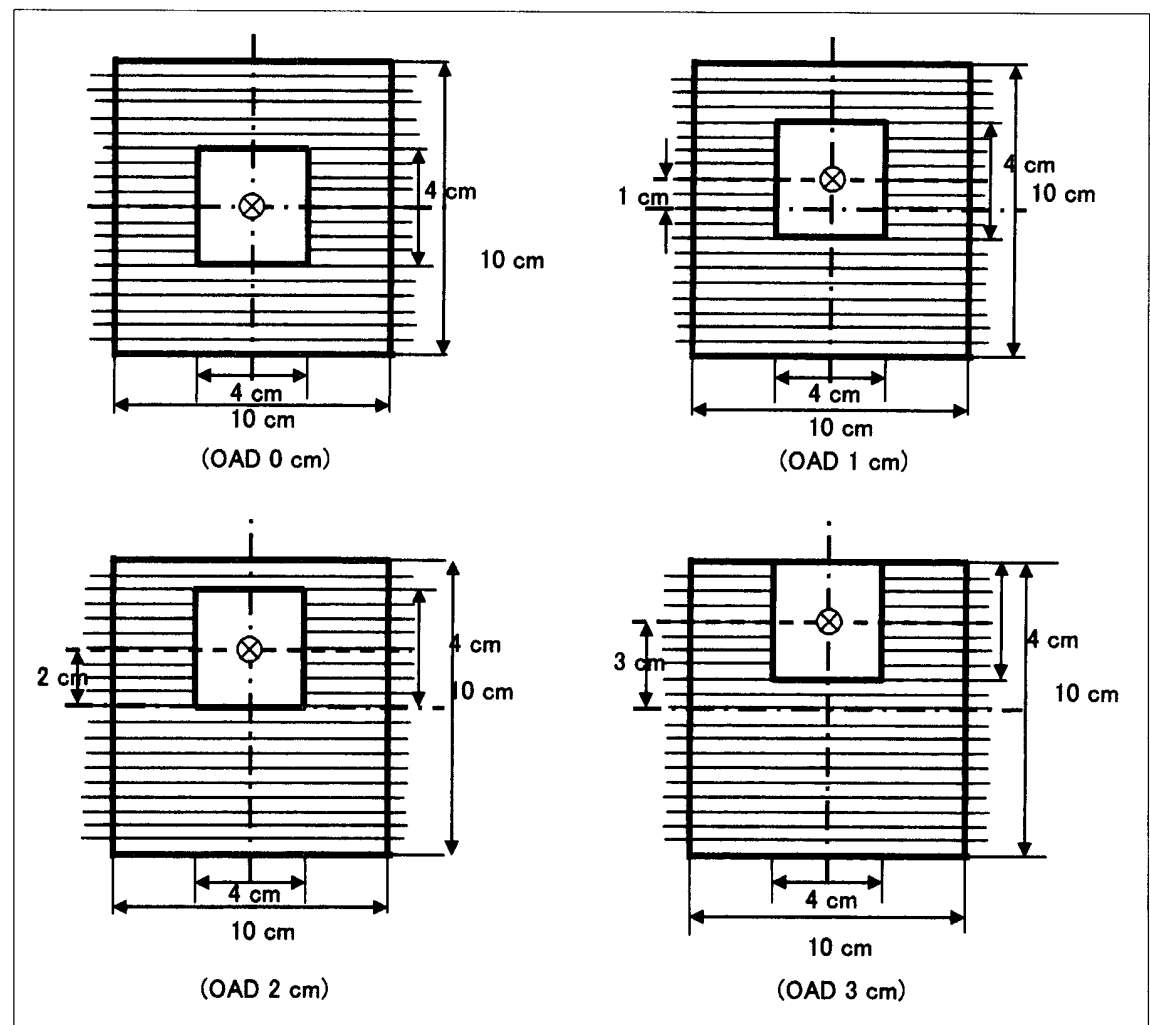

Fig. 7 Diagram showing irregular field shapes, off-axis distances (OADs), and dose evaluation points.

Table 5 Accuracy of $10 \mathrm{MV}$ X-ray $S_{c}, S_{p}$, and TPR $\left(10,15 \mathrm{~cm}\right.$ depths) values calculated for an $\mathrm{MLC}$ field of $4 \times 4 \mathrm{~cm}^{2}$ with a main collimator opening of $10 \times 10 \mathrm{~cm}^{2}$ as a function of $O A D$.

(a) Without SSC and $F_{\text {MLC }}$ corrections.

(a) (b) With SSC and $F_{\text {MLC }}$ corrections.

\begin{tabular}{|c|c|c|c|c|c|c|c|c|c|c|c|c|}
\hline \multirow{2}{*}{$\mathrm{OAD}(\mathrm{cm})$} & \multicolumn{3}{|c|}{$S_{c}$} & \multicolumn{3}{|c|}{$S_{p}$} & \multicolumn{3}{|c|}{$\operatorname{TPR}(10 \mathrm{~cm})$} & \multicolumn{3}{|c|}{ TPR $(15 \mathrm{~cm})$} \\
\hline & Calculated & Measured & $\%$ Devi & Calculated & Measured & \%Devi & Calculated & Measured & $\%$ Devi & Calculated & Measured & $\%$ Devi \\
\hline 0 & 1 & 0.9781 & 2.24 & 0.9542 & 0.9741 & -2.04 & 0.8483 & 0.8531 & -0.56 & 0.7152 & 0.7201 & -0.68 \\
\hline 1 & 1 & 0.9786 & 2.19 & 0.9542 & 0.9747 & -2.10 & 0.8483 & 0.8519 & -0.42 & 0.7152 & 0.7171 & -0.26 \\
\hline 2 & 1 & 0.9790 & 2.15 & 0.9542 & 0.9758 & -2.21 & 0.8483 & 0.8506 & -0.27 & 0.7152 & 0.7153 & -0.01 \\
\hline 3 & 1 & 0.9786 & 2.19 & 0.9542 & 0.9779 & -2.42 & 0.8483 & 0.8496 & -0.15 & 0.7152 & 0.7135 & 0.24 \\
\hline Mean & & & 2.19 & & & 2.20 & & & 0.35 & & & 0.30 \\
\hline \multicolumn{13}{|l|}{ (b) } \\
\hline \multirow{2}{*}{$\mathrm{OAD}(\mathrm{cm})$} & \multicolumn{3}{|c|}{$S_{c}$} & \multicolumn{3}{|c|}{$S_{p}$} & \multicolumn{3}{|c|}{ TPR $(10 \mathrm{~cm})$} & \multicolumn{3}{|c|}{$\operatorname{TPR}(15 \mathrm{~cm})$} \\
\hline & Calculated & Measured & $\%$ Devi & Calculated & Measured & \%Devi & Calculated & Measured & $\%$ Devi & Calculated & Measured & $\%$ Devi \\
\hline 0 & 0.9807 & 0.9781 & 0.27 & 0.9663 & 0.9741 & -0.80 & 0.8536 & 0.8531 & 0.06 & 0.7209 & 0.7201 & 0.11 \\
\hline 1 & 0.9807 & 0.9786 & 0.21 & 0.9663 & 0.9736 & -0.75 & 0.8536 & 0.8519 & 0.20 & 0.7209 & 0.7171 & 0.53 \\
\hline 2 & 0.9807 & 0.9790 & 0.17 & 0.9663 & 0.9758 & -0.97 & 0.8536 & 0.8506 & 0.35 & 0.7209 & 0.7153 & 0.78 \\
\hline 3 & 0.9807 & 0.9786 & 0.21 & 0.9663 & 0.9779 & -1.19 & 0.8536 & 0.8496 & 0.47 & 0.7209 & 0.7135 & 1.04 \\
\hline Mean & & & 0.22 & & & 0.93 & & & 0.27 & & & 0.62 \\
\hline
\end{tabular}

る。不整形照射野 $(\mathrm{J})$ では, 主コリメー夕照射野が $10 \times 10 \mathrm{~cm}^{2}$ である． $S_{\mathrm{p}}$-Clarkson積分法で求めたMLC等 価正方形照射野辺は $4.07 \mathrm{~cm}$ となる，不整形照射野 $(\mathrm{K})$ では，主コリメー夕照射野が $12 \times 12 \mathrm{~cm}^{2}$ である。不整 形照射野 (I)では，主コリメー夕照射野が $10 \times 10 \mathrm{~cm}^{2}$ で ある。不整形照射野 $(\mathbf{M})$ では，主コリメータ照射野が $6 \times 8 \mathrm{~cm}^{2}$ である。不整形照射野 $(\mathrm{K}-\mathrm{M})$ では，それぞれに 対してMLC照射野は同じであり， $S_{\mathrm{p}}$-Clarkson積分法で
求めたMLC等価正方形照射野辺は $3.55 \mathrm{~cm}$ となる.

\section{3-6 不整形照射野のSSC係数}

Fig. $3(\mathrm{a})$ - (m)に表した不整形照射野 (A-M)における SSC係数をTable 7に示守. Fig. 3(a)-(g)の不整形照射 野はSSC係数 $\geq 1$ の值をとり，Fig. 3(k)-(m)の不整形照 射野はSSC係数<1の值をとる。 
Table 6 Equivalent square field sizes obtained using the mapping method for main collimator fields and those obtained using the $S_{p}$-Clarkson method for MLC fields.

\begin{tabular}{lccccccc}
\hline \multicolumn{1}{c}{ Irreg. Field } & A & B & C & D & E & F & G \\
\hline Main Colli F.S. $\left(\mathrm{cm}^{2}\right)$ & $5 \times 5$ & $14.2 \times 14.2$ & $6 \times 20$ & $20 \times 6$ & $20 \times 20$ & $20 \times 20$ & $14 \times 8$ \\
Field Mapping $(\mathrm{cm})$ & 5 & 14.2 & 11.23 & 7.83 & 20 & 20 & 9.34 \\
$S_{p}$-Clarkson $(\mathrm{cm})$ & 4.58 & 9.84 & 8.68 & 8.74 & 14.98 & 15.15 & 6.45 \\
\hline
\end{tabular}

\begin{tabular}{lcccccc}
\hline \hline Irreg.Field & $\mathrm{H}$ & $\mathrm{I}$ & $\mathrm{J}$ & $\mathrm{K}$ & $\mathrm{L}$ & $\mathrm{M}$ \\
\hline Main Colli F.S. $\left(\mathrm{cm}^{2}\right)$ & $6 \times 10$ & $10 \times 10$ & $10 \times 10$ & $12 \times 12$ & $10 \times 10$ & $6 \times 8$ \\
Field Mapping $(\mathrm{cm})$ & 8.18 & 10 & 10 & 12 & 10 & 7.2 \\
S -Clarkson $(\mathrm{cm})$ & 4.53 & 2.07 & 4.07 & 3.55 & 3.55 & 3.55 \\
\hline
\end{tabular}

\section{3-7 MLC不整形照射野での線量評価}

コリメータ散乱係数 $\left(S_{\mathrm{c}}\right)$ の測定值はコリメー夕回転 中心軸より変位している場合, アルミ製ビルドアップ キャップ使用でX線ビームに対して垂直に配置した場 合の值である。フフントム散乱係数 $\left(S_{\mathrm{p}}\right)$ および組織フ アントム線量比(TPR)の基準深は $5 \mathrm{~cm}$ とし，検討した 深さは $10 \mathrm{~cm}$ と $15 \mathrm{~cm}$ である.

\section{3-7-1 SSC係数=1の場合}

Fig. 3(a)-(g)に示す不整形照射野 (A-G)に対する等 価正方形照射野辺を適用したコリメー夕散乱係数 $\left(S_{\mathrm{c}}\right)$ ，ファントム散乱係数 $\left(S_{\mathrm{p}}\right)$ および組織ファントム 線量比(TPR)の計算値を実測值とともにTable 8 (a), (b)に示す. Table $8(\mathrm{a})$ は $F_{\mathrm{MLC}}$ 補正係数=1 と仮定した 場合である (SSC係数=1)：Table 8(b) は，Fig. 5の実線 から得た $F_{\mathrm{MLC}}$ 補正係数を用いた場合である $(\mathrm{SSC}$ 係 数=1).

Fig. $3(\mathrm{a})$ - (g)での不整形照射野 (A-G) に関しては, コリメー夕散乱係数 $\left(S_{\mathrm{c}}\right)$ の平均誤差は $0.22 \%$ であ.

Table $8(a)$ に示すように, $F_{\mathrm{MLC}}$ 補正係数=1 と仮定した 場合の計算では, ファントム散乱係数 $\left(S_{\mathrm{p}}\right)$ の平均誤差 は $0.25 \%$, 深さ $10 \mathrm{~cm}$ での組織ファントム線量比 (TPR)の平均誤差は $0.1 \%$, 深さ $15 \mathrm{~cm}$ での組織ファン トム線量比(TPR)の平均誤差は $0.18 \%$ となる. Table 8(b)に示すように, Fig. 5の実線からの $F_{\mathrm{MLC}}$ 補正係数 を用いた場合では，ファントム散乱係数 $\left(S_{\mathrm{p}}\right)$ の平均誤 差は $0.27 \%$, 深さ $10 \mathrm{~cm}$ での組織ファントム線量比 (TPR)の平均誤差は $0.23 \%$, 深さ $15 \mathrm{~cm} て ゙ の$ 組織ファ ントム線量比(TPR)の平均誤差は $0.52 \%$ となる：ファ ントム散乱係数 $\left(S_{\mathrm{p}}\right)$ おうよび組織ファントム線量比 (TPR)を $F_{\mathrm{MLC}}$ 補正係数で補正しない方が全般的にわず かであるが計算精度は高い。しか儿，個々のデータで はFig. 5 の実線からの $F_{\mathrm{MLC}}$ 補正係数を用いた場合の方 が計算精度も高くなる場合もある。

\section{3-7-2 SSC係数 $<1$ の場合}

Fig. 3(h)-(m)に示す不整形照射野 (H-M)に対する等
Table 7 Relationship between the SSC factor and the ratio of MLC square field side/main collimator square field side for irregular fields A-M.

\begin{tabular}{cccc}
\hline $\begin{array}{c}\text { Irregular } \\
\text { field }\end{array}$ & MLC/Coll & SSC & $\begin{array}{c}\text { Calculated } \\
\text { (SSC) }\end{array}$ \\
\hline A & 0.917 & 1 & $(1.0102)$ \\
B & 0.693 & 1 & $(1.0024)$ \\
C & 0.773 & 1 & $(1.0072)$ \\
D & 1.115 & 1 & $(1.0242)$ \\
E & 0.749 & 1 & $(1.0033)$ \\
F & 0.758 & 1 & $(1.0035)$ \\
G & 0.691 & 1 & $(1.0022)$ \\
H & 0.554 & 0.9942 & $(0.9942)$ \\
I & 0.207 & 0.9660 & $(0.9660)$ \\
J & 0.407 & 0.9809 & $(0.9809)$ \\
K & 0.296 & 0.9693 & $(0.9693)$ \\
L & 0.355 & 0.9769 & $(0.9769)$ \\
M & 0.493 & 0.9912 & $(0.9912)$ \\
\hline
\end{tabular}

価正方形照射野辺を適用したコリメー夕散乱係数 $\left(S_{\mathrm{c}}\right)$ ，ファントム散乱係数 $\left(S_{\mathrm{p}}\right)$ および組織ファントム 線量比(TPR)の計算值を実測值とともに結果をTable 9 (a), (b)に示す.

Table 9(a)は, SSC係数=1および $F_{\mathrm{MLC}}$ 補正係数=1 $=1$ と 仮定した場合である。コリメー夕散乱係数 $\left(S_{\mathrm{c}}\right)$ の平均 詔差は $1.98 \%$ ，ファントム散乱係数 $\left(S_{\mathrm{p}}\right)$ の平均誤差は $2.04 \%$, 深さ $10 \mathrm{~cm}$ での組織ファントム線量比 (TPR)の 平均誤差は $0.57 \%$, 深さ $15 \mathrm{~cm}$ での組織ファントム線 量比(TPR)の平均誤差は $1.01 \%$ あ゙あ.

Table 9(b) は，計算に基づいたSSC係数抢よびFig. 5の 実線からの $F_{\mathrm{MLC}}$ 補正係数を用いた場合である.コリメ 一夕散乱係数 $\left(S_{\mathrm{c}}\right)$ の平均誤差は $0.25 \%$, ファントム散乱 係数 $\left(S_{\mathrm{p}}\right)$ の平均詔差は $0.61 \%$, 深さ $10 \mathrm{~cm}$ での組織ファ ントム線量比 (TPR)の平均誤差は $0.18 \%$, 深さ $15 \mathrm{~cm}$ の組織ファントム線量比(TPR)の平均誤差は $0.2 \%$ であ る. 計算に基づいたSSC係数およびFig. 5の実線からの

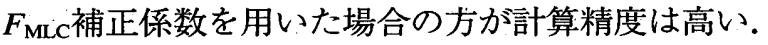


Table 8 Accuracy of $S_{c}, S_{p}$, and TPR (10, $15 \mathrm{~cm}$ depths) values calculated for $10 \mathrm{MV}$ X-ray irregular fields A-G.

(a) Without SSC and $F_{M L C}$ corrections.

(b) With SSC and $F_{\mathrm{MLC}}$ corrections.

(a)

\begin{tabular}{|c|c|c|c|c|c|c|c|c|c|c|c|c|}
\hline \multirow{2}{*}{ Irreg. Field } & \multicolumn{3}{|c|}{$S_{\mathrm{c}}$} & \multicolumn{3}{|c|}{$S_{p}$} & \multicolumn{3}{|c|}{ TPR $(10 \mathrm{~cm})$} & \multicolumn{3}{|c|}{$\operatorname{TPR}(15 \mathrm{~cm})$} \\
\hline & Calculated & Measured & \%Devi & Calculated & Measured & \%Devi & Calculated & Measured & \%Devi & Calculated & Measured & $\%$ Devi \\
\hline A & 0.9698 & 0.9697 & 0.01 & 0.9653 & 0.9627 & 0.27 & 0.8529 & 0.8526 & 0.04 & 0.7180 & 0.7202 & -0.31 \\
\hline B & 1.0120 & 1.0121 & -0.01 & 0.9993 & 1.0015 & -0.22 & 0.8764 & 0.8778 & -0.16 & 0.7572 & 0.7576 & -0.05 \\
\hline C & 1.0043 & 1.0010 & 0.33 & 0.9940 & 0.9970 & -0.30 & 0.8726 & 0.8712 & 0.16 & 0.7508 & 0.7470 & 0.51 \\
\hline $\mathrm{D}$ & 0.9891 & 0.9849 & 0.43 & 0.9943 & 0.9965 & -0.22 & 0.8727 & 0.8730 & -0.03 & 0.7511 & 0.7516 & -0.07 \\
\hline E & 1.0206 & 1.0206 & 0.00 & 1.0162 & 1.0159 & 0.03 & 0.8893 & 0.8886 & 0.08 & 0.7787 & 0.7775 & 0.15 \\
\hline $\mathrm{F}$ & 1.0206 & 1.0190 & 0.16 & 1.0167 & 1.0176 & -0.09 & 0.8911 & 0.8896 & 0.17 & 0.7793 & 0.7799 & -0.08 \\
\hline $\mathrm{G}$ & 0.9967 & 0.9904 & 0.64 & 0.9815 & 0.9877 & -0.63 & 0.8635 & 0.8629 & 0.07 & 0.7356 & 0.7350 & 0.08 \\
\hline Mean & & & 0.22 & & & 0.25 & & & 0.10 & & & 0.18 \\
\hline
\end{tabular}

\begin{tabular}{|c|c|c|c|c|c|c|c|c|c|c|c|c|}
\hline \multirow{2}{*}{ Irreg. Field } & \multicolumn{3}{|c|}{$S_{c}$} & \multicolumn{3}{|c|}{$S_{p}$} & \multicolumn{3}{|c|}{$\operatorname{TPR}(10 \mathrm{~cm})$} & \multicolumn{3}{|c|}{$\operatorname{TPR}(15 \mathrm{~cm})$} \\
\hline & Calculated & Measured & $\% \mathrm{Devi}$ & Calculated & Measured & $\%$ Devi & Calculated & Measured & \%Devi & Calculated & Measured & $\%$ Devi \\
\hline A & 0.9698 & 0.9697 & 0.01 & 0.9655 & 0.9627 & 0.29 & 0.8530 & 0.8526 & 0.05 & 0.7181 & 0.7202 & -0.29 \\
\hline B & 1.0120 & 1.0121 & -0.01 & 1.0025 & 1.0015 & 0.10 & 0.8788 & 0.8778 & 0.11 & 0.7612 & 0.7576 & 0.48 \\
\hline C & 1.0043 & 1.0010 & 0.33 & 0.9962 & 0.9970 & -0.08 & 0.8742 & 0.8712 & 0.34 & 0.7534 & 0.7470 & 0.86 \\
\hline D & 0.9891 & 0.9849 & 0.43 & 0.9913 & 0.9965 & -0.52 & 0.8706 & 0.8730 & -0.27 & 0.7474 & 0.7516 & -0.56 \\
\hline$E$ & 1.0206 & 1.0206 & 0.00 & 1.0195 & 1.0159 & 0.35 & 0.8911 & 0.8886 & 0.28 & 0.7817 & 0.7775 & 0.54 \\
\hline $\mathrm{F}$ & 1.0206 & 1.0190 & 0.16 & 1.0199 & 1.0176 & 0.23 & 0.8914 & 0.8896 & 0.20 & 0.7822 & 0.7799 & 0.29 \\
\hline G & 0.9967 & 0.9904 & 0.64 & 0.9848 & 0.9877 & -0.29 & 0.8659 & 0.8629 & 0.35 & 0.7396 & 0.7350 & 0.63 \\
\hline Mean & & & 0.22 & & & 0.27 & & & 0.23 & & & 0.52 \\
\hline
\end{tabular}

Table 9 Accuracy of $S_{c}, S_{p}$, and TPR $(10,15 \mathrm{~cm}$ depths $)$ values calculated for $10 \mathrm{MV}$ X-ray irregular fields $\mathrm{H}$-M.

(a) Without SSC and $F_{M L C}$ corrections.

(a)

(b) With SSC and $F_{\text {MLC }}$ corrections.

\begin{tabular}{|c|c|c|c|c|c|c|c|c|c|c|c|c|}
\hline \multirow{2}{*}{ Irreg. Field } & \multicolumn{3}{|c|}{$S_{c}$} & \multicolumn{3}{|c|}{$S_{p}$} & \multicolumn{3}{|c|}{ TPR $(10 \mathrm{~cm})$} & \multicolumn{3}{|c|}{$\operatorname{TPR}(15 \mathrm{~cm})$} \\
\hline & Calculated & Measured & $\%$ Devi & Calculated & Measured & $\%$ Devi & Calculated & Measured & $\%$ Devi & Calculated & Measured & $\%$ Devi \\
\hline $\mathrm{H}$ & 0.9910 & 0.9819 & 0.93 & 0.9649 & 0.9755 & -1.09 & 0.8526 & 0.8543 & -0.20 & 0.7175 & 0.7232 & -0.79 \\
\hline 1 & 1.0000 & 0.9673 & 3.38 & 0.8670 & 0.9227 & -6.04 & 0.8357 & 0.8390 & -0.39 & 0.6959 & 0.7041 & -1.16 \\
\hline $\mathrm{J}$ & 1.0000 & 0.9796 & 2.08 & 0.9584 & 0.9689 & -1.08 & 0.8493 & 0.8526 & -0.39 & 0.7120 & 0.7208 & -1.22 \\
\hline $\mathrm{K}$ & 1.0065 & 0.9831 & 2.38 & 0.9464 & 0.9650 & -1.93 & 0.8451 & 0.8554 & -1.20 & 0.7129 & 0.7245 & -1.60 \\
\hline $\mathrm{L}$ & 1.0000 & 0.9783 & 2.22 & 0.9464 & 0.9575 & -1.16 & 0.8451 & 0.8508 & -0.67 & 0.7129 & 0.7184 & -0.77 \\
\hline$M$ & 0.9855 & 0.9766 & 0.91 & 0.9464 & 0.9556 & -0.96 & 0.8451 & 0.8497 & -0.54 & 0.7129 & 0.7168 & -0.54 \\
\hline Mean & & & 1.98 & & & 2.04 & & & 0.57 & & & 1.01 \\
\hline \multicolumn{13}{|l|}{ (b) } \\
\hline \multirow{2}{*}{ Irreg. Field } & \multicolumn{3}{|c|}{$S_{c}$} & \multicolumn{3}{|c|}{$S_{p}$} & \multicolumn{3}{|c|}{$\operatorname{TPR}(10 \mathrm{~cm})$} & \multicolumn{3}{|c|}{$\operatorname{TPR}(15 \mathrm{~cm})$} \\
\hline & Calculated & Measured & $\%$ Devi & Calculated & Measured & \%Devi & Calculated & Measured & $\%$ Devi & Calculated & Measured & \%Devi \\
\hline $\mathrm{H}$ & 0.9852 & 0.9819 & 0.34 & 0.9694 & 0.9755 & -0.63 & 0.8564 & 0.8543 & 0.25 & 0.7238 & 0.7232 & 0.08 \\
\hline I & 0.9660 & 0.9673 & -0.13 & 0.9049 & 0.9227 & -1.93 & 0.8383 & 0.8390 & -0.08 & 0.7026 & 0.7041 & -0.21 \\
\hline$J$ & 0.9809 & 0.9796 & 0.13 & 0.9675 & 0.9689 & -0.14 & 0.8545 & 0.8526 & 0.22 & 0.7207 & 0.7208 & -0.01 \\
\hline $\mathrm{K}$ & 0.9757 & 0.9831 & -0.75 & 0.9624 & 0.9650 & -0.27 & 0.8512 & 0.8554 & -0.49 & 0.7209 & 0.7245 & -0.50 \\
\hline L & 0.9769 & 0.9783 & -0.14 & 0.9615 & 0.9575 & 0.42 & 0.8508 & 0.8508 & 0.00 & 0.7202 & 0.7184 & 0.25 \\
\hline$M$ & 0.9768 & 0.9766 & 0.02 & 0.9581 & 0.9556 & 0.26 & 0.8492 & 0.8497 & -0.06 & 0.718 & 0.7168 & 0.17 \\
\hline Mean & & & 0.25 & & & 0.61 & & & 0.18 & & & 0.20 \\
\hline
\end{tabular}


Table 10. SSC factor of irregular field with MLC (A-M), using A/P method, and collimator scatter factor $\left(S_{c}\right)$.

\begin{tabular}{crrrrr}
\hline $\begin{array}{c}\text { Irregular } \\
\text { field }\end{array}$ & SSC & $\begin{array}{c}\text { Calculated } \\
(S S C)\end{array}$ & $S_{\mathrm{c}}$ & \%Devi & $\begin{array}{c}\text { Measured } \\
S_{\mathrm{c}}\end{array}$ \\
\hline A & 1 & $(1.0098)$ & 0.9698 & 0.01 & 0.9697 \\
B & 0.9890 & $(0.9890)$ & 1.0009 & -1.11 & 1.0121 \\
C & 1 & $(1.0154)$ & 0.9951 & -0.59 & 1.0010 \\
D & 1 & $(1.0151)$ & 0.9951 & 1.04 & 0.9849 \\
E & 0.9985 & $(0.9985)$ & 1.0191 & -0.15 & 1.0206 \\
F & 0.9985 & $(0.9985)$ & 1.0191 & 0.01 & 1.0190 \\
G & 0.9837 & $(0.9837)$ & 0.9837 & -0.68 & 0.9904 \\
H & 0.9923 & $(0.9923)$ & 0.9796 & -0.23 & 0.9819 \\
I & 0.9639 & $(0.9639)$ & 0.9639 & -0.35 & 0.9673 \\
J & 0.9737 & $(0.9737)$ & 0.9737 & -0.60 & 0.9796 \\
K & 0.9653 & $(0.9653)$ & 0.9716 & -1.17 & 0.9831 \\
L & 0.9729 & $(0.9729)$ & 0.9729 & -0.55 & 0.9783 \\
M & 0.9884 & $(0.9884)$ & 0.9723 & -0.44 & 0.9766 \\
\hline
\end{tabular}

\section{4. 羌 霓}

小照射野でのコリメー夕散乱係数 $\left(S_{\mathrm{c}}\right)$ 測定では， ミ ニファントム $(4 \mathrm{~cm} \phi)$ を用いると, それが照射野内に 完全に入らないことがある.この場合には，直径のよ り小さなミニファントムの使用, 線源からの測定距離 を長くすることや金属製ビルドアップキャップを用い ることがある. Table 1 (a)，(b) 押よびTable 2(a)，(b) では，照射野 $2 \times 2 \mathrm{~cm}^{2}$ 未満のX線ナロービームでのコリ メータ散乱係数 $\left(S_{\mathrm{c}}\right)$ は線源検出間距離 $(\mathrm{SCD}) 300 \mathrm{~cm}$ で アルミ製ビルドアップキャップ $(2.7 \mathrm{~cm} \phi)$ を用いて測定 した.このような測定条件下でも，半影効果によりビ ルドアップキャップ全体が均一に照射されていない可 能性がある，このことが表值に示されるように，SSC 係数に関する計算結果の誤差に反映されているかも知 れない. 主コリメー夕照射野 $1 \times 1 \mathrm{~cm}^{2}$ でのコリメータ 散乱係数 $\left(S_{\mathrm{c}}\right)$ では, アクリル製ミニ・ファントム $(1 \mathrm{~cm} \phi, \mathrm{SCD} 140 \mathrm{~cm})$ とアルミ製ビルドアップギャッ プ $(2.7 \mathrm{~cm} \phi, \mathrm{SCD} 300 \mathrm{~cm})$ の相違は非常に小さい(約 0.5 \%)。われわれの測定では照射室の大きさなどの制約 があり，さらに長い線源検出間距離を取れなかったた めに，半影効果の影響を完全に排除できなかったのが 大きな理由と思われる。

式(2)のMLC照射野の等価正方形照射野辺 $\left(S_{M L C}^{e q}\right)$ を 求めるのに, JacksonらはA/P法を用いているが; われ われは $S_{\mathrm{p}}$-Clarkson積分法を採用した. Fig. 3(e)， $(\mathrm{g}) ，(\mathrm{~h})$ および $(\mathrm{m})$ の不整形照射野において，A/P法 によるSSC係数から求めたコリメー夕散乱係数 $\left(S_{\mathrm{c}}\right)$ と 実測によるそれとを比較すると，Fig. 3(e)では-0.2 \%, Fig. 3 (g)では-0.7\%, Fig 3(h)では-0.2\%および Fig. $3(\mathrm{~m})$ では-0.4\%の相違となる (Table 10). 両者に は有意差がみられない.しかしながら， $S_{M L C}^{e q}$ は式(5) にも用いられている(この式ではファントム内での線
量計算を行っている): よって，この場合は一般にA/ P法より $S_{\mathrm{P}-C l a r k s o n}$ 積分法が優れている.

不整形照射野のコリメー夕散乱係数 $\left(S_{\mathrm{c}}\right)$ を評価する 方法として, 主コリメータ等価正方形照射野辺に対す るMLC等価正方形照射野辺の比が約 0.64 以上の場 合, SSC係数は 1 以上になる (Fig. 4). 主コリメー夕 正方形照射野内にMLC正方形照射野が辺の長さで約 6 割入り込んでもコリメー夕散乱係数 $\left(S_{\mathrm{c}}\right)$.の值は主コリ メータ開度のみのデータをそのまま用いることができ ることになる. 主コリメー夕等価正方形照射野辺に対 するMLC等価正方形照射野辺の比が約 0.64 未満では SSC係数は 1 より小さくなる (Fig. 4)：この場合, 主 コリメータ照射野に比べて，MLC照射野が極端に小 さいので主コリメー夕開度のみによるコリメー夕.散乱 係数 $\left(S_{\mathrm{c}}\right)$ をそのまま用いることはできない. 主コリメ 一夕開度のみのコリメー夕散乱係数 $\left(S_{\mathrm{c}}\right)$ にJacksonらの SSC係数 (1-1参照)で補正することにより，MLC付き のコリメータ散乱係数 $\left(S_{\mathrm{c}}\right)$ の計算精度は向上する。

Fig. $3(\mathrm{e}) ，(\mathrm{~g}) ，(\mathrm{~h}) ，(\mathrm{~m})$ の不整形照射野につい て，A/P法による等価正方形照射野辺 ( $\left.S_{M L C}^{e q}\right)$ をいて 得たファントム散乱係数 $\left(S_{\mathrm{P}}\right)$ 拀よび組織ファントム線

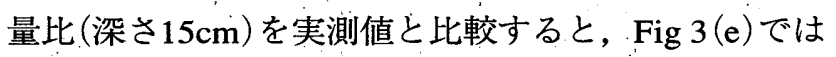
それぞれ-0.7\%, - $1: 0 \%$, Fig 3(g)ではそれぞれ-2.4 $\%,-2.4 \%$, Fig. 3(h)ではそれぞれ-2.2\%, $-1.2 \%$, Fig. 3. m)ではそれぞれ-2.9\%, - $1.3 \%$ と大きな相違と なっている.われわれが採用した $S_{\mathrm{p}}$-Clarkson積分法の 方がTable 8(a), Table 9(a)に示すように, より計算 精度が高いことが分かる。

Table 8(b), Table 9(b) より, 次のことが理解できる. ファントム散乱係数 $\left(S_{\mathrm{p}}\right)$ においてて，MLC照射野を $S_{\mathrm{p}}$ Clarkson積分法で等価正方形照射野辺を求め, これと主 コリメータ等価正方形照射野辺との比を関数にした $F_{\mathrm{MLC}}$ 
補正係数(Fig. 5)で補正することにより，線量計算精度 は向上する， $F_{\mathrm{MLC}}$ 補正係数はMLCの物理的特性(X線の 透過，リーフ間の洩れ，リーフ先端からの散乱など)に よる線量の影響を考慮した係数である。また，組織フ アントム線量比にもわずかであるが上記の影響が反映 されている。これらのことを如実に表しているのが， Fig. 3(k)，(1)および $(\mathrm{m})$ での不整形照射野であり，これ にみられるように，主コリメータ開度をMLCの作る照 射野ちょうどまで閉じる方が計算精度は高い.

今回の $S_{\mathrm{p}}$-Clarkson積分法での実験結果からは，主コ リメー夕等価正方形照射野辺に対するMLC等価正方 形照射野辺の比が約 0.6 以下の場合は， $F_{\mathrm{MLC}}$ 補正係数 を適応すると高精度の線量計算が可能となることが分 かった。

われわれが使用している放射線治療計画装置 (Focus) では，Khanの提唱している全散乱係数 $\left(S_{\mathrm{cp}}\right)$ お よびファントム散乱係数 $\left(S_{\mathrm{p}}\right)$ を入力しなければならな い. Clarkson積分法を用いて不整形照射野を等価正方 形照射野に換算する場合，散乱最大線量比(SMR) を利 用することもできるが，ファントム散乱係数 $\left(S_{\mathrm{p}}\right)$ を利 用することも可能である。

矩形照射野のX線ビームが患者の皮膚面からはみで ている領域をMLC不整形照射野で覆うことは，場合 によってはX線出力の低下を招く恐れがある。このよ

うなMLC使用は避けるべきである。

今後,この方法を $4 \mathrm{MVX}$ X線に対して拡張したいと考 えている.

\section{5. 結 猃}

不整形照射野において，主コリメー夕照射野に比べ
て，MLC照射野が小さい場合の線量評価は，コリメ 一夕散乱係数 $\left(S_{\mathrm{c}}\right)$ とファントム散乱係数 $\left(S_{\mathrm{p}}\right)$ を用いる ことにより計算精度が向上した．MLC照射野が相対 的に非常に小さい場合には，コリメータ散乱係数 $\left(S_{\mathrm{c}}\right)$ の評価にSSC係数を導入することにより精度は高くな った。またフフントム散乱係数 $\left(S_{\mathrm{p}}\right)$ を用いた Clarkson積分法で求めた等価正方形照射野にMLC漏洩 補正係数 $\left(F_{\mathrm{MLC}}\right)$ を導入することにより，計算精度が向 上した。

\section{付録 $\mathrm{SSC}$ 係数の計算例}

式 (5)の不整形照射野のコリメー夕散乱係数 $S_{\mathrm{c}}$ (Coll+MLC)の計算をFig. $3(\mathrm{e})$ および $(\mathrm{m})$ に表した照 射野の場合について記する。

（I)Fig. 3 (e)では，SSC係数 $\geq 1$ の場合である. 式(1)よ り, $\mathrm{G}=0.655$ となる. $S_{M L C}^{e q}=14.98 \mathrm{~cm}$ より, $S_{\mathrm{c}}\left(S_{M L C}^{e q}\right)$ $=1.0131$ となる. $S_{\text {coll }}^{e q}=20 \mathrm{~cm}$ であるから $S_{\mathrm{c}}\left(S_{\text {coll }}^{e q} \times \mathrm{G}\right)$ $=1.0098$ となる. よって, 式(2)により, $\mathrm{SSC}=1.0131 /$ $1.0098=1.0033$ となるので, $\mathrm{SSC}=1$ と設定する。よっ て, $S_{\mathrm{c}}\left(S_{\text {coll }}^{\text {eq }}\right)=1.0206$ であるから, 式 $(3)$ により $S_{\mathrm{c}}$ $($ Coll+MLC $)=1.0206 \times 1=1.0206$ となる．

（II)Fig. $3(\mathrm{~m})$ では, SSC係数<1の場合である. 式(1) より, $\mathrm{G}=0.655$ である. $S_{M L C}^{e q}=3.55 \mathrm{~cm}$ より,$S_{\mathrm{c}}\left(S_{M L C}^{e q}\right)$ $=0.9589$ となる． $S_{\text {coll }}^{e q}=7.19 \mathrm{~cm}$ であるから $S_{\mathrm{c}}\left(S_{\text {coll }}^{e q} \times \mathrm{G}\right)$ $=0.9675$ となる.よって式(2)により， $\mathrm{SSC}=0.9589 /$ $0.9675=0.9912$ となる。よって, $S_{\mathrm{c}}\left(S_{\text {coll }}^{\text {eq }}\right)=0.9855$ であ

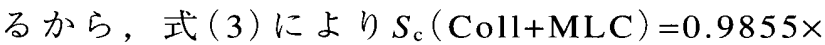
$0.9912=0.9768$ となる

\section{参考文献}

1) Khan FM, Sewchand W, Lee J, et al.: Revision of tissuemaximum ratio and scatter-maximum ratio concepts for cobalt 60 and Higher x-rays beams. Med Phys, 7 (3), 230-237, (1980).

2) 日本医学物理学会編：外部放射線治療における吸収線量の 標準測定法(標準測定法01)。通商産業研究社，(2002).

3) Yu MK, Murray B, and Sloboda R: Parametrization of headscatter factors for rectangular fields using an equivalent square formalism. Med Phys, 22, 1329-1332,(1995).

4) Kim S, Zhu TC, and Palta JR: An equivalent square field formula for determining head scatter factors of rectangular fields. Med Phys, 24, 1770-1774, (1997).

5) Jackson DD, Colleen LH, and Dennis DV: Small MLC seg- ment monitor units for IMRT. CMS Japan user group materials, (2001).

6) Venselaar JLM, Heukelom S, Jager HN, et al.: Is there a need for a revised table of equivalent square fields for the determination of phantom scatter correction factors? Phys Med Biol, 42, 2369-2381, (1997).

7) Clarkson JR: A note on depth dose in fields of irregular shape. Brit J Radiol, 14, 265, (1941).

8) Cunningham JR: Scatter-air ratio. Phys Med Biol, 17, 42-51, (1972).

9) Bjärngard BE: Separation of primary and scatter components of measured photon beam data. Phys Med Biol, 34, 1939-1945, (1989). 


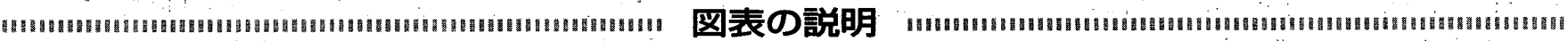

Fig. 1 不整形照射野の幾何係数 $(G)$ を求める幾何学的配置図

下段コリメータとMLC間の幾何学的関係も表している.

Fig. 2 Clarkson積分法による等価正方形照射野辺を求める図

Fig. 3 不整形照射野(A-M)の形状と線量評価点を示す図

Fig. 4 主コリメ゙ータ正方形照射野辺に対するMLC正方形照射野辺の比とSSC係数の関係を示す図

Fig. 5: 主コリメータ正方形照射野辺に対するMLC正方形照射野辺の比との関数で表した10MV X線ファントム散乱係数 $\left(S_{\mathrm{p}}\right)$ に対 する補正係数 三角印が深さ $2.5 \mathrm{~cm}$, 四角印が深さ $5 \mathrm{~cm}$, 丸印が深さ $10 \mathrm{~cm}$ および+印が深さ $15 \mathrm{~cm}$ での值を示す。

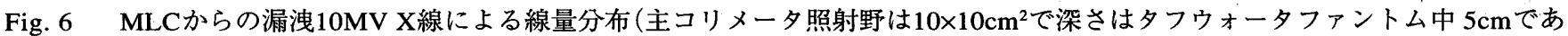
る).

Fig. 7 不整形照射野の形状，off-axis distance (OAD)の大きさ，線量評価点を示す図

Table 1 10MV X線における不整形照射野のsmall segment correction (SSC) 係数とコリメータ散乱係数 $\left(S_{\mathrm{c}}\right)$ の計算精度. 主コリメー 夕照射野 $(\mathrm{a}) 6 \times 6 \mathrm{~cm}^{2}$, （b) $8 \times 8 \mathrm{~cm}^{2}$.

Table 2 10MV X線における不整形照射野のsmall segment correction (SSC) 係数とコリメー夕散乱係数 $\left(S_{\mathrm{c}}\right)$ の計算精度. 主コリメー 夕照射野 (a) $10 \times 10 \mathrm{~cm}^{2}$ ，(b) $16 \times 16 \mathrm{~cm}^{2}$.

Table 3 10MV X線の主コリメータ照射野一定でMLC照射野の $S_{\mathrm{cp}}$ (深さ $5 \mathrm{~cm}$ )， $S_{\mathrm{c}}, S_{\mathrm{p}}$ (深さ $5 \mathrm{~cm}$ ), ESFS，ESFS/MLC. 主コリメー 夕照射野 $(\mathrm{a}) 6 \times 6 \mathrm{~cm}^{2}$, ，(b) $8 \times 8 \mathrm{~cm}^{2}$.

Table $410 \mathrm{MV}$ X線の主コリメー夕照射野一定でMLC照射野の $S_{\mathrm{cp}}$ (媣さ $5 \mathrm{~cm}$ )， $S_{\mathrm{c}}, S_{\mathrm{p}}$ (深さ $5 \mathrm{~cm}$ ), ESFS, ESFS/MLC. 主コリメー 夕照射野 (a) $10 \times 10 \mathrm{~cm}^{2}$, (b) $16 \times 16 \mathrm{~cm}^{2}$.

Table 5 10MVX線において主コリメー夕照射野 $10 \times 10 \mathrm{~cm}^{2} ，$ MLC照射野 $4 \times 4 \mathrm{~cm}^{2}$ に対して，OADを変えた場合の計算精度 $\left[S_{\mathrm{c}} ， S_{\mathrm{p}}\right.$ ， TPR (深さ $10 \mathrm{~cm}, \cdot 15 \mathrm{~cm})]$.

(a) SSC係数と $F_{\mathrm{MLC}}$ 補正係数による補正がない場合，（b)SSC係数と $F_{\mathrm{MLC}}$ 補正係数による補正がある場合.

Table 6 主コリメータ照射野に対して照射野マッピング法で求めた等価正方形照射野辺ならびにMLC照射野に対して $S_{\mathrm{p}}$ 用いたク ラークソン積分法で求めた等価正方形照射野辺.

Table 7 SSC係数と主コリメータ正方形照射野辺に対するMLC正方形照射野辺の比との関係[不整形照射野 (A-M)].

Table 8 10MV X線にお拈りる不整形照射野 $(\mathrm{A}-\mathrm{G})$ の計算精度 $\left[S_{\mathrm{c}}, S_{\mathrm{p}}\right.$, TPR (深さ10,15cm)].

(a) SSC係数と $F_{\mathrm{MLC}}$ 補正係数による補正がない場合，(b)SSC係数と $F_{\mathrm{MLC}}$ 補正係数による補正がある場合.

Table 9１0MV X線における不整形照射野 $(\mathrm{H}-\mathrm{M})$ の計算精度 $\left[S_{\mathrm{c}}, S_{\mathrm{p}}, \mathrm{TPR}\right.$ (深さ10，15cm) ].

(a) SSC係数と $F_{\mathrm{MLC}}$ 補正係数による補正がない場合，(b)SSC係数と $F_{\mathrm{MLC}}$ 補正係数による補正がある場合.

Table 10 A/P法によるMLC不整形照射野 $(\mathrm{A}-\mathrm{M})$ )SSC係数とコリメー夕散乱係数 $\left(S_{\mathrm{c}}\right)$ 